\title{
Income inequality, residential poverty clustering and infant mortality: a study in Rio de Janeiro, Brazil
}

\author{
Célia Landmann Szwarcwald*, Carla Lourenço Tavares de Andrade, \\ Francisco Inácio Bastos
}

Departamento de Informações em Saúde, Fundação Oswaldo Cruz., Biblioteca de Manguinhos \# 205, Av. Brasil 4365, Rio de Janeiro, RJ, 21045-900, Brazil

\begin{abstract}
In this paper, we propose an approach to investigate the hypothesis that the residential concentration of poverty affects health status more deeply than when poverty is randomly scattered in a given geographical area. To characterize the geographic pattern of poverty in the city of Rio de Janeiro, Brazil, an index that measures the heterogeneity of poverty concentration among sub-areas was proposed. We used census data and defined poverty by means of the household head monthly income. The 153 neighborhoods that compose the city were used as the geographic units, and the census tracts as the sub-areas. The proposed index measures differences of poverty concentration across census tracts within a neighborhood. The effects of geographic poverty clustering on infant mortality related variables (early neonatal mortality rate; post-neonatal mortality rate; proportion of adolescent mothers; and fertility rate among adolescents) were estimated by partial correlation coefficients, controlling for the neighborhood poverty rate. Our study revealed that intra-city variations of the post-neonatal mortality rate are associated with geographic patterns of poverty, and that pregnancy in adolescence is strongly and contextually correlated with intra-neighborhood poverty clustering, even after adjustment for the poverty rate. The evidence of relevant health differences associated with the spatial concentration of poverty supports the hypothesis that properties of the environment of residence contextually influence health. Our findings suggest that prevention of some infant mortality related problems has to be focused directly on features of communities, considering their physical, cultural and psychosocial characteristics, being of particular concern the health of communities segregated from the society at large by extreme poverty. (C) 2002 Elsevier Science Ltd. All rights reserved.
\end{abstract}

Keywords: Income inequality; Poverty clustering; Pregnancy in adolescence; Brazil; Rio de Janeiro

\section{Introduction}

The inverse association between a person's socioeconomic status and health status is by now well established (Marmot, Kogeniva, \& Elston, 1987; Towsend \& Davidson, 1990; Adler, Boyce, Chesney, Folkman, \& Syme, 1993; Sorlie, Backlund, \& Keller, 1995). The general pattern is that the higher the individual income the lower the risk of disease and mortality. The

\footnotetext{
*Corresponding author. Tel.: + 55-221-290-1696/+55-221598-4366; fax: + 55-221-270-2668.

E-mail address: celials@fiocruz.br (C.L. Szwarcwald).
}

relationship is described by a curvilinear decreasing function with a nonlinear gradient, steeper at low income levels than at high income levels (Duncan, 1996; Backlund \& Sorlie, 1996).

Researchers have suggested that not only the absolute standard of living but also the magnitude of the gap between the rich and the poor matter in terms of population health (Wilkinson, 1996). Indeed, over the last few years, the income inequality hypothesis has been confirmed by a substantial number of studies, considering distinct ecological levels such as states within countries (Kaplan, Pamuck, Lynch, Cohen, \& Balfour, 1996; Kennedy, Kawachi, \& Prothrow-Smith, 1996; 
Wolfson, Kaplan, Lynch, Ross, \& Backlund, 1999), metropolitan areas of the United States (Lynch et al., 1998), and districts within metropolitan regions of Brazil (Szwarcwald, Bastos, Viacava, \& Andrade, 1999). These studies have consistently shown that the more concentrated the income the worse the population health status.

Although the existence of the association between income inequality and health status seems secure, mathematical analyses indicate that this association may be, at least partly, a statistical artifact produced by using aggregated data rather than individual data (Gravelle, 1998). In other words, the association between income inequality and health status reported in some studies may be simply due to the aggregation of low-income individuals within areas, resulting from analyses that have not adequately controlled for confounding by income measured at the individual level (Fiscella \& Franks, 1997).

The relevance of distinguishing compositional from contextual effects has been emphasized in recent years (Diez-Roux, 1998; Shouls, Congdon, \& Curtis, 1996). Compositional effects act simply because of the population composition of types of people whose individual characteristics influence their health. Contextual effects operate when the health status of individuals depends not only on their own characteristics but also on the supra-individual effects associated with the area where they live or the social group to which they belong. In statistical terms, the estimation of the income inequality contextual effect has to take into account the individual income variations and the intra-area correlated observations (Humphreys \& Carr-Hill, 1991). Through multilevel modeling it is possible to assess compositional, contextual and interaction effects simultaneously (Wong \& Mason, 1991).

Under this perspective, a few recent studies have used multilevel modeling to estimate contextual income inequality effects after adjustment for individual income. Some of these investigations have shown that the social context has an independent role on the association between income inequality and health status (Shouls et al., 1996; Kennedy, Kawachi, Glass, \& ProthrowSmith, 1998). Sampson, Raudenbush, and Earls (1998) used a measure of collective efficacy to show that social and organizational characteristics of communities are important to understand crime rate differences, which are not completely explained by the aggregated individual characteristics. On the other hand, some other studies have suggested that there is little residual variation in mortality associated with contextual variables, once individual differences in socioeconomic status are accounted for (Reijneveld, 1998; Slogget \& Joshi, 1994; Fiscella \& Franks, 1997).

However, multiple level modeling may not be the ideal strategy to assess contextual effects, since individual level characteristics may mask the effect of income inequality at the population level (Lynch, Smith, Kaplan, \& House, 2000). That is, estimating the contextual effect of income inequality on health outcomes via multilevel modeling is complicated by the possible existence of collinearity among individual income, income inequality and poverty concentration, variables that are usually closely linked (Fiscella \& Franks, 1997). As has been discussed by Massey (1996), rising disparity in income distribution along with increasing class segregation have produced a geographic concentration of poverty and affluence in many countries. As a result, societies with large income inequalities are likely to have higher levels of individual poverty as well as residential poverty concentration (Kawachi \& Kennedy, 1997).

To understand the linkages between those variables, investigations should focus on features of the areas rather than on the compositional characteristics of the area residents, which cannot fully describe the social environment in which people live (Macintyre, Maciver, \& Sooman, 1993). So, an alternative strategy to assess the contextual effects of the inequality of the income distribution is to study the influence of the geographic pattern of poverty on health outcomes.

Brazil is a typical case of an extremely unequal society, with the highest $10 \%$ accounting for $51 \%$ of the total income (World Bank, 1995). For reasons related to the political-economic process of development, including serious deficiencies in basic education, disparities in terms of social opportunities have widened over the last three decades, contributing to accelerate the gap between rich and poor (Sen, 1999). The intense migration of unskilled people to the metropolitan areas in the Southeast has established a peculiar geographic pattern of residential inequality in those areas, with a considerable part of the population living in situations of extreme poverty. The residential geography of Rio de Janeiro, the second biggest city in Brazil, is, nowadays, characterized by the spread of slums (favelas) throughout the city. These low-income communities are generally characterized by lack of basic infrastructure services, inadequate housing, and excessive crowding.

Although many health policies have been implemented to mitigate effects of poverty, the incomplete economic transition is reflected by the strong heterogeneity of the infant mortality in the country (Bacha \& Klein, 1986). Differently from the process experienced in other countries, such as Taiwan (Chiang, 1999), in Brazil, distinct socioeconomic and health patterns coexist and frequently overlap. The heterogeneity of the infant mortality is nowadays expressed at different geographic levels, from macro-regional differences to intra-state and intra-city variations (Sastry, 1996). If at some geographic levels, absolute poverty is the key explanatory variable, for variation within metropolitan 
areas, residential poverty clustering seems to be the most important factor (Szwarcwald et al., 1999; Szwarcwald, Bastos, Barcellos, Pina, \& Esteves, 2000).

In this paper, aiming to examine the influence of the geographic pattern of poverty in the city of Rio de Janeiro on the infant mortality rate, we develop an approach to investigate the hypothesis that the residential concentration of poverty affects the health status of communities more deeply than when poverty is randomly scattered. We define an index that measures the heterogeneity of poverty concentration among subareas to analyze the effects of geographic poverty clustering on the infant mortality rate (early neonatal and post-neonatal mortality rates), and on the fertility rate among adolescent women, in the city of Rio de Janeiro, Brazil, 1995-96.

\section{Methodology}

In order to describe the geographic pattern of poverty, we use an index that measures the heterogeneity of poverty concentration among sub-areas (Appendix). The idea is to distinguish the effects of situations of concentrated poverty in a small number of sub-areas from (hypothetical) situations of randomly distributed poverty. As illustrated in Fig. 1, two geographical areas can have exactly the same proportion of poor people, but different spatial distributions of poverty.

To examine the spatial distribution of poverty in the city of Rio de Janeiro, Brazil, we used 1991 census data and defined poverty by means of the household head monthly income. We considered that an "event" occurred when the household head monthly income was reported to be less than the poverty level in Brazil (approximately US\$80.00).

The 153 neighborhoods that compose the city were used as the geographic units, and the census tracts as the sub-areas. The proposed index measures differences of poverty rates across census tracts within neighborhood. For each neighborhood with more than five census tracts, the index of heterogeneity of poverty concentration among sub-areas was calculated.

To estimate the infant mortality rate, mortality data were obtained from the Mortality Information System compiled by the Rio de Janeiro Secretariat of Health. All reported deaths in 1995-96 of children aged less than 1 year old, residents in the City of Rio de Janeiro, were considered in the study.

Information on number of live births as well as on characteristics of the mothers were obtained from the Rio de Janeiro Information System of Live Births, for the same period of time. For the sake of the analysis, neighborhoods with less than 300 live births in the period of time 1995-96 were not considered in the study. The indicators related to the infant mortality rate were

\begin{tabular}{|c|c|c|c|c|c|c|c|c|c|c|c|c|c|c|c|}
\hline \multicolumn{16}{|c|}{ Randomly Distributed Poverty } \\
\hline$\square$ & $\square$ & व & $\square$ & & 口 & 口 & & $\square$ & - & $\square$ & & 口 & $\square$ & 口 & \\
\hline - & 口 & $\square$ & $\square$ & $\square$ & a & a & व & $\square$ & 口 & 口 & $\square$ & 口 & 口 & 口 & - \\
\hline - & 口 & 口 & 口 & $\square$ & व & - & 口 & $\square$ & 口 & $\square$ & $\square$ & 口 & 口 & 口 & 口 \\
\hline$\square$ & $\square$ & 口 & $\square$ & $\square$ & 口 & - & 口 & $\square$ & $\square$ & $\square$ & $\square$ & - & $\square$ & 口 & - \\
\hline$\square$ & $\square$ & $\square$ & - & $\square$ & $\square$ & ם & व & - & - & 口 & $\square$ & 口 & 口 & . & 口 \\
\hline 口 & 口 & व & 口 & 口 & व & " & व & 口 & 口 & 口 & " & 口 & 口 & 口 & 口 \\
\hline D & $\square$ & . & $\square$ & $\square$ & 口 & 口 & - & $\square$ & 口 & - & $\square$ & D & D & - & - \\
\hline . & . & 口 & ם & 口 & व & व & - & 口 & 口 & 口 & 口 & - & 口 & 口 & 口 \\
\hline a & a & . & व & . & " & व & - & 口 & 口 & 口 & $\square$ & 口 & 口 & 口 & 口 \\
\hline D & a & a & 口 & $\square$ & 口 & 口 & व & $\square$ & 口 & 口 & $\square$ & 口 & 口 & 口 & 口 \\
\hline 口 & 口 & - & " & - & व & व & व & 口 & 口 & 口 & 口 & 口 & 口 & 口 & 口 \\
\hline 口 & $\mathrm{a}$ & 口 & 口 & 口 & 口 & " & 口 & . & 口 & . & 口 & 口 & . & - & 口 \\
\hline
\end{tabular}

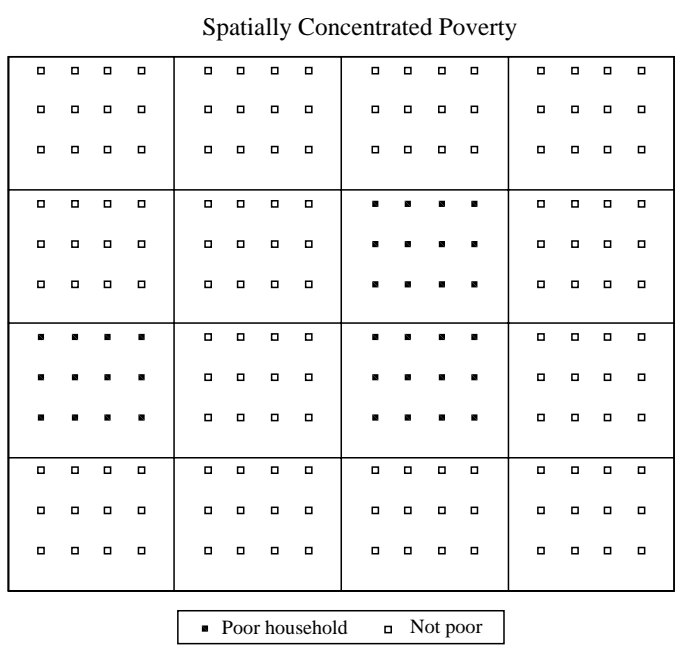

Fig. 1. Example of areas with different geographic poverty patterns.

calculated for the years 1995-96, because 1995 was the first year for which the mortality data system provided information on neighborhood of residence.

For each neighborhood, the following indicators were considered:

(i) Poverty rate-defined as the proportion of poor household heads among the total number of household heads.

(ii) Average income - defined as the average monthly income of the household heads.

(iii) Gini coefficient - a well-known measure of income inequality.

(iv) Index of heterogeneity of poverty concentration among sub-areas - the proposed index (Appendix).

(v) Infant Mortality Rate-defined as the number of deaths of infants under 1 year of age per 1000 live births. 
(vi) Early Neonatal Mortality Rate-infant mortality rate in the first 6 days of life.

(vii) Post-neonatal Mortality Rate-infant mortality rate in the post-neonatal period (28-365 days).

(viii) Proportion of adolescent mothers-defined as the proportion of mothers aged 10-19 years among all women that gave birth in 1995-96.

(ix) Fertility rate among adolescents-defined as the number of babies born to women of 10-19 years per 1000 women of that age.

Descriptive statistics for all variables considered in the study were calculated. Pearson's correlation coefficients among all variables under analysis were estimated. Student's $t$-tests were used to test the significance of the associations among the socioeconomic indexes and response variables. The effects of the "index of heterogeneity of poverty concentration" on the health outcomes (infant mortality rate and its components "early neonatal mortality rate" and "post-neonatal mortality rate"; "proportion of adolescent mothers"; and "fertility rate among adolescents") were estimated via partial correlation coefficients, after controlling for the "poverty rate" and "average income".

\section{Results}

From the 153 residential neighborhoods in Rio de Janeiro, 121 satisfied the criteria of inclusion (number of life births greater than 300 and number of census tracts greater than 5). Basic descriptive statistics of all variables considered in the study are presented in Table 1. The median "early neonatal mortality rate" was 10 per 1000 live births and the median "postneonatal mortality rate" was 7 per 1000 live births. Maximum values of 42 (for the early neonatal mortality rate) and 24 per 1000 live births (for the post-neonatal mortality rate) indicate that the infant mortality varia- tions by neighborhood of residence are very wide. The "proportion of adolescent mothers" varied from $3 \%$ to $26 \%$, and showed a skewed distribution with a median value of $19 \%$. The "fertility rate among adolescents" had a median value of 76 and the third quartile was equal to 109 per 1000 women aged 10-19 years. The wide ranges of the "poverty rate" $(4-44 \%)$ and of the "index of heterogeneity poverty concentration among sub-areas" (0.011-0.133) showed not only great differences of poverty rates among neighborhoods but also across census tracts within neighborhoods. Worth of note is the maximum value of the Gini coefficient (0.71), expressing the great disparity in the distribution of income. This can also be evidenced by the enormous range of variation of the average income among neighborhoods, with a minimum value of US\$135.00 and a maximum value of US\$2406.00.

The matrix of correlation coefficients is presented in Table 2. The components of the infant mortality rate are significantly correlated with each other, with the "proportion of adolescent mothers", and with the "poverty rate". The "proportion of adolescent mothers" is strongly and positively correlated with the "poverty rate" and negatively with the "average income". Regarding the socioeconomic indices-the "poverty rate", the "average income" and the "Gini coefficient" the first two are highly and inversely correlated, but the latter is significantly correlated only to the proportion of poverty. In respect to the proposed index - the "heterogeneity of poverty concentration among sub-areas" - a strong and direct correlation with the "Gini coefficient" was found, indicating that the more unequal the distribution of income the more poverty is spatially aggregated.

Also, one can observe that there is no correlation between the "poverty rate" and the "index of heterogeneity of poverty concentration" (Table 2), indicating that the two indexes have different meanings. The first

Table 1

Descriptive statistics of all variables considered in the study

\begin{tabular}{lccrrr}
\hline Variables & Median & First quartile & Third quartile & Minimum value & Maximum value \\
\hline Early neonatal mortality rate (1000 live births) & 10.48 & 6.99 & 13.05 & 0.00 & 42.45 \\
Post-neonatal mortality rate (1000 live births) & 6.88 & 4.66 & 9.63 & 0.00 & 23.58 \\
Proportion of adolescent mothers (\%) & 18.52 & 15.69 & 21.33 & 3.22 & 26.23 \\
Poverty rate (\%) & 0.21 & 0.15 & 0.28 & 0.04 & 0.44 \\
Gini coefficient & 0.48 & 0.47 & 0.51 & 0.42 & 0.71 \\
Index of heterogeneity of poverty intensity & 0.04 & 0.03 & 0.07 & 0.01 & 0.13 \\
Average income (\$) & 297.45 & 229.64 & 459.33 & 135.20 & 2405.60 \\
Fertility rate among adolescents & 37.78 & 25.12 & 54.62 & 5.07 & 261.90 \\
Population & 30,769 & 18,321 & 50,840 & 2104 & 258,780 \\
Number of census tracts & 36 & 21 & 59 & 6 & 295 \\
\hline
\end{tabular}


Table 2

Matrix of correlations among all variables considered in the study

\begin{tabular}{|c|c|c|c|c|c|c|c|c|}
\hline Variables & 1 & 2 & 3 & 4 & 5 & 6 & 7 & 8 \\
\hline 1. Early neonatal mortality rate & 1.00 & & & & & & & \\
\hline 2. Post-neonatal mortality rate & $0.54^{* *}$ & 1.00 & & & & & & \\
\hline 3. Proportion of adolescent mothers & $0.24^{* *}$ & $0.27^{* *}$ & 1.00 & & & & & \\
\hline 4. Poverty rate & $0.20^{*}$ & $0.27^{* *}$ & $0.85^{* *}$ & 1.00 & & & & \\
\hline 5. Gini coefficient & 0.04 & -0.03 & 0.16 & $0.20^{*}$ & 1.00 & & & \\
\hline 6. Index of heterogeneity of poverty intensity & 0.17 & $0.24^{* *}$ & $0.29^{* *}$ & 0.17 & $0.29^{* *}$ & 1.00 & & \\
\hline 7. Average income & -0.02 & -0.03 & $-0.77^{* *}$ & $-0.69^{* *}$ & -0.01 & 0.03 & 1.00 & \\
\hline 8. Fertility rate among adolescents & 0.04 & 0.08 & $0.39^{* *}$ & $0.36^{* *}$ & 0.16 & $0.31^{* *}$ & $-0.36^{* *}$ & 1.00 \\
\hline
\end{tabular}

** Correlation is significant at the 0.01 level.

* Correlation is significant at the 0.05 level.

Table 3

Partial correlation coefficients controlling for "poverty rate" and for "average income"

\begin{tabular}{|c|c|c|c|c|}
\hline \multirow[t]{2}{*}{ Variables } & \multicolumn{2}{|c|}{ Controlling for "poverty rate" } & \multicolumn{2}{|c|}{ Controlling for "average income" } \\
\hline & $\begin{array}{l}\text { Index of heterogeneity } \\
\text { of poverty intensity }\end{array}$ & Gini coefficient & $\begin{array}{l}\text { Index of heterogeneity } \\
\text { of poverty intensity }\end{array}$ & Gini coefficient \\
\hline $\begin{array}{l}\text { Early neonatal } \\
\text { mortality rate }\end{array}$ & $\begin{array}{l}0.144 \\
p=0.117\end{array}$ & $\begin{array}{l}-0.045 \\
p=0.961\end{array}$ & $\begin{array}{l}0.173 \\
P=0.058\end{array}$ & $\begin{array}{c}0.035 \\
p=0.703\end{array}$ \\
\hline $\begin{array}{l}\text { Post-neonatal } \\
\text { mortality rate }\end{array}$ & $\begin{array}{l}0.202 \\
p=0.027\end{array}$ & $\begin{array}{l}-0.085 \\
p=0.354\end{array}$ & $\begin{array}{l}0.239 \\
P=0.008\end{array}$ & $\begin{array}{l}-0.026 \\
p=0.778\end{array}$ \\
\hline $\begin{array}{l}\text { Proportion of } \\
\text { adolescent } \\
\text { mothers }\end{array}$ & $\begin{array}{l}0.273 \\
p=0.003\end{array}$ & $\begin{array}{l}-0.036 \\
p=0.696\end{array}$ & $\begin{array}{l}0.489 \\
P=0.000\end{array}$ & $\begin{array}{c}0.228 \\
p=0.012\end{array}$ \\
\hline $\begin{array}{l}\text { Fertility rate } \\
\text { among } \\
\text { adolescents }\end{array}$ & $\begin{array}{l}0.265 \\
p=0.003\end{array}$ & $\begin{array}{c}0.091 \\
p=0.324\end{array}$ & $\begin{array}{l}0.341 \\
p=0.000\end{array}$ & $\begin{array}{c}0.162 \\
p=0.077\end{array}$ \\
\hline
\end{tabular}

measures the proportion of poor people within each neighborhood, whether they are concentrated or not, and the second is a measure of the spatial pattern of poverty concentration/dispersion within the neighborhood, independent of the magnitude of the "poverty rate".

The partial correlation coefficients between each health outcome and the "index of heterogeneity of poverty concentration among sub-areas", controlling for the "poverty rate", are presented in Table 3. The highest partial correlation was shown for the "proportion of adolescent mothers" ( $p=0.003)$ followed closely by the "fertility rate among adolescents" $(p=0.003)$. A less expressive but significant partial correlation was found for the "post-neonatal mortality rate" $(p=0.027)$. A non-significant association was found for the "early neonatal mortality rate" $(p=0.117)$. After adjusting for the average income, the results were similar, but the partial correlation coefficients were much stronger.
Other key findings presented in Table 3 are the partial correlation coefficients between the "Gini coefficient" and the "proportion of adolescent mothers". After adjustment for the "average income", the partial correlation is statistically different from zero $(p=0.012)$. However, after controlling for the "poverty rate", the partial correlation is negative and is not significantly different from zero $(p=0.696)$. These results suggest that the association between health outcomes and indices of income inequality may result simply from the compositional effect of poverty aggregation within an area. On the other hand, the partial correlation coefficients between the "proportion of adolescent mothers" and the "index of heterogeneity of poverty concentration among sub-areas" are highly significant in both situations, whether controlling for the poverty rate or for the average income, suggesting that the index of residential poverty clustering was able to separate the contextual from the compositional poverty effect. 


\section{Discussion}

In the present paper, we examined the association of infant mortality related variables to the spatial pattern of poverty in the City of Rio de Janeiro at two levels of analysis. At the first one, we analyzed the effects of the between-neighborhood variation of socioeconomic indicators and at the second one, the effects of the intraneighborhood pattern of poverty clustering, after controlling for the total neighborhood poverty rate.

Our study revealed not only that the intra-city variations of the post-neonatal mortality rate are associated with the geographic pattern of poverty but also that pregnancy in adolescence is strongly and contextually correlated with the intra-neighborhood poverty clustering, even after adjustment for the neighborhood poverty rate. The evidence of relevant health differences associated to the spatial pattern of poverty concentration clearly supports the hypothesis that properties of the environment of residence contextually influence health.

The results indicate that the association between the infant mortality rate and poverty concentration occurs at both levels of analysis. At the first one, we have found strong and significant correlations between the infant mortality indicators, the proportion of adolescent mothers and the poverty rate. At the second level, the significance of the partial correlation coefficients when controlling for the poverty rate has shown the effects of the intra-neighborhood variation of poverty.

The analysis of the association between infant mortality and socioeconomic indicators at the level of neighborhoods within the city has shown that poverty concentration is the best predictor of the outcomes. Neither the average income nor the income inequality indicator (Gini coefficient) has shown to be significantly correlated with the response variables, corroborating previous findings (Szwarcwald et al., 2000).

The lack of correlation between average income and the infant mortality rate can be explained by the extreme variation of socioeconomic conditions within some neighborhoods of the city. For example, the neighborhood of São Conrado comprises a very deprived community and the most luxurious houses of Rio de Janeiro. This neighborhood has at the same time the highest average income among all neighborhoods under analysis and a very high infant mortality rate, due to the poverty concentration in its slum area.

It is important to mention that the effects of poverty on infant mortality are in part being reversed by adequate prenatal care, as shown elsewhere (Andrade \& Szwarcwald, 2001). However, as discussed by Gama, Szwarcwald, Leal, and Theme Filha (2001), Brazilian adolescent mothers have a lower number of appointments and a higher percentage of no attendance, when compared to 20-24 year-old mothers. So, pregnancy in adolescence, lack of prenatal care, poverty, and low educational level, have a synergic role in the determination of high levels of infant mortality. Therefore, the association of the poverty rate to the outcomes at the neighborhood level is probably expressing effects of distal and proximal variables, all of them core factors in the causation web of infant mortality.

Now, at the second level of analysis, the correlation of the post-neonatal mortality rate and within-neighborhood poverty clustering may be explained by the "neomaterial interpretation" of the inequality income effects (Lynch et al., 2000). The excess of infant deaths associated to poverty segregation by place of residence is probably reflecting the geographical concentration of cumulative forms of disadvantages intensified by adverse exposures to infectious diseases. As shown by Victora (2000), infectious diseases contribute substantially to infant mortality in Brazil. Among the five leading causes of infant mortality in the country, respiratory infections (largely pneumonia), diarrhea, and other infections such as sepsis and meningitis account for, respectively, $10 \%$, $8 \%$ and $6 \%$ of the total infant deaths (Victora, 2000). In the last decades, a substantial decrease in the number of deaths due to respiratory infections and diarrhea has been observed, but rates remain unacceptably high among the poor and underserved segments of the population (Monteiro \& Benicio, 1989).

Among the main determinant factors are inadequacy of housing and sanitation, poor access to health care, and other cultural factors affecting use of preventive services, as a result of the systematic underinvestment in social infrastructure, public education, health care services, and other social goods (Kawachi, Kennedy, Lochner, \& Prothrow-Smith, 1997; Smith, 1996; Kaplan et al., 1996).

Another interesting result is that no significant correlation was found between the early neonatal mortality rate and the index of heterogeneity of poverty concentration per unit area, after adjustment for poverty rate. This finding confirms the well-known fact that the socio-environmental factors are predominantly related to the post-neonatal mortality rate and indicates that infant mortality comparisons from different areas are made more meaningful if the infant death data are classified into age groups (Rip, Keen, \& Woods, 1987). Previous findings (Szwarcwald et al., 2000) have shown that the infant mortality rate, unlike other health indicators, follows a unique geographic pattern. The variations found in the infant mortality geographical distribution have been explained by the strong relationship between early neonatal mortality and access to health care facilities.

"The proportion of adolescent mothers" and the "fertility rate among adolescents" have shown to be better indicators of the effect resulting from residential 
poverty segregation, with strong correlations with the index of heterogeneity of poverty concentration among sub-areas, even after adjustment for poverty proportion. The contextual poverty effect that affects pregnancy in adolescence may be examined not only as a material consequence of living in an unequal society but also under the "psychosocial environment interpretation" (Wilkinson, 1997), which considers that income inequality may affect health via psychosocial processes. According to this interpretation, people's perception of relative deprivation may promote increased levels of frustration, hopelessness, hostility, shame and distrust, which may result in risk taking behavior that affect health.

A substantial number of variables that influence adolescent pregnancy have been identified previously (Barnett, Papini, \& Gbur, 1991). These variables include socioeconomic factors, school performance, family instability, and fertility patterns of the communities in which the adolescent live (Faber, 1991). The group of poor adolescents that live in the favelas of Rio de Janeiro are clearly at risk for early pregnancy: many of them have low educational attainment, live in families of which mothers are the only breadwinners, and have mothers who also had had their own children in early ages.

Besides these cumulative negative factors, Sciarra and Ponterotto (1998) have suggested that the feeling of ownership is also a strong motivator for motherhood among teenage residents in low-income communities. In the sense that a baby represents something they will possess forever, early motherhood is an attempt to restore stability and permanence to their own lives. Ethnographic work carried out in a deprived community of Rio de Janeiro (Vigário Geral) (Monteiro, 1999) showed that poor young women regarded early marriage and maternity as a chance to recompose their (lost) family life, and a core opportunity to fulfill personal aspirations. Those aspirations are essentially linked to family life since most of them lack basic educational and training skills essential to meet the demands of a restrictive (not to say, discriminatory) labor market.

A further aspect related to adolescent childbearing is the polarization between male and female roles in the favelas. In a society still marked by the machismo, specially among low-income and illiterate people, the street is seen as the focus of male activities and the home as the focus of female activities, which encourages the adolescent decision to become pregnant (Sciarra \& Ponterotto, 1998; Monteiro, 1999).

Pregnancy during adolescence is a major public health problem in Brazil. Fertility rates are decreasing in all age groups, exception made to adolescents (10-19 years old) (Gama et al., 2001). Apart from the adverse effects on maternal and infant health, early motherhood is of particular concern because it is considered as a core element in the process of "transmitting" poverty (Stern, 1997). A teenage birth cuts the mother's possibility of adequate schooling, limits her potential to find a wellremunerated job, which in turn reduces the opportunities of appropriate education for her children, in such a way that this situation persists across generations.

Our findings indicate that class stratification by place of residence has important influence on the problem of adolescent pregnancy. So, thinking about prevention, we have to focus direct attention to low-income adolescents that live segregated in deprived communities and implement actions at the scale of whole communities (Puska et al., 1989; Farquhar et al., 1990; Shouls et al., 1996). Bearing in mind that the goal is the individual behavioral change which in turn depends on transformation of deeply ingrained social norms, the next step is to investigate what aspects of the psychosocial and cultural environment need to be tackled to assure changes in the adolescent conduct (Yen \& Syme, 1999).

Among the major challenges facing strategies to test the income inequality hypothesis is to model both individual-level and contextual-level factors, distinguishing the individual effects from the contextual effects (Diez-Roux, Link, \& Northridge, 2000). An important strength of our approach was the ability to detect a contextual income inequality effect after controlling the compositional effect of poverty taken at the individual level.

A well-known index to distinguish between-neighborhood variation from within-neighborhood variation in poverty is Jargowsky's "neighborhood sorting index" (Jargowsky, 1996), which is based on the ratio of the variance of income between groups to the variance within groups. However, in our analysis, poverty rate has shown to have a more important role than the mean income in the explanation of the infant mortality rate variation at the neighborhood level. So, in the present paper, we used an equivalent approach for estimation of within-group variance of proportions, based on the $\chi^{2}$ statistics, which is more appropriate for testing withinneighborhood effects of the poverty rate.

The proposed index was able to measure the heterogeneity of poverty intensity across census tracts and indicated that our actions to prevent the associated health problems have to move beyond individuals to the communities in which people live. However, a better comprehension of the pathways through which geographic poverty clustering affects the health outcomes is still needed. Our effort to make evident the correlation between health outcomes and poverty spatial clustering may contribute to a better understanding of the level of influence of the environmental factors. Determining why the health outcome distribution is associated with the geographic pattern of poverty is the next stage of the investigation. Our approach identified that 
neighborhood poverty clustering has an impact on some health outcomes beyond that which is attributable to individual characteristics, but was unable to explain how this feature of the social environmental affects health.

Despite the limitations of our methodological approach, results are conclusive in at least four aspects:

- Firstly, they highlight an important contextual income inequality effect - the socioeconomic stratification by place of residence - which remains even after adjustment for the individual income compositional effect.

- Secondly, they support the hypothesis that residential poverty clustering affects the health of communities more deeply than when poverty is randomly scattered.

- Thirdly, they show there are important intra-city infant mortality variations, which are associated with the geographic pattern of poverty.

- Finally, they indicate that prevention of some infant mortality related problems has to be focused directly on features of communities, taking into account their physical, cultural and psychosocial characteristics of the communities. Deprived communities, segregated from the society at large by dire poverty, are of special concern and should constitute the very priority of public health initiatives.

\section{Appendix A. An index of heterogeneity of poverty concentration among sub-areas}

The approach here proposed is adapted from the statistical test $\left(\chi^{2}\right)$ of heterogeneity (Zar, 1996) and from a spatial technique that is usually applied to identify point location patterns (Upton \& Fingleton, 1985). Consider that all household locations are points in the geographic areas under investigation. The term "event" is used for the occurrence of a poor individual household at a point location. Consider also that each geographic area $i$ is subdivided in $k_{i}$ sub-areas, and let $n_{i j}$ be the number of residents in sub-area $j, O_{i j}$ the number of poor residents in sub-area $j, O_{i}$ the total number of poor residents in geographic area $i$, and $n_{i}$ the total number of residents in geographic area $i$.

Then, the poverty concentration in geographic area $i$ per unit area is given by:

$p_{i}=\frac{O_{i}}{n_{i}}$.

Under the hypothesis of homogeneity of the poverty distribution among sub-areas, the expected values are calculated by:

$E_{i j}=n_{i j} p_{i}$
So, we define the "index of heterogeneity of poverty intensity per unit area" as the Cramér's contingency coefficient (Zar, 1996) expressed by:

$\Phi_{\lambda}=\sqrt{\frac{\chi^{2}}{\left(k_{i}-1\right) O_{i}}}$,

where

$\chi^{2}=\sum_{j=1}^{k_{i}} \frac{\left(O_{i j}-E_{i j}\right)^{2}}{E_{i j}}$.

The proposed coefficient is based upon $\chi^{2}$, meaning that the more homogeneity among the sub-area poverty rates, the more the index approaches zero, and viceversa. It is divided by the $\chi^{2}$ degrees of freedom $\left(k_{i}-1\right)$, to take into account the number of sub-areas the whole geographic area is divided, and by $O_{i}$, to consider the total number of poor people in each geographic unit, as well.

\section{References}

Adler, N., Boyce, W. T., Chesney, M. A., Folkman, S., \& Syme, S. L. (1993). Socioeconomic differences in health: No easy solution. Journal of the American Medical Association, 269(24), 3140-3145.

Andrade, C. L. T., \& Szwarcwald, C. L. (2001). Análise especial da mortalidade neonatal precoce no Município do Rio de Janeiro, 1995-96 [in Portuguese]. Cadernos de Saúde Pública 17(5), 1199-1210.

Bacha, E., \& Klein, H. (Eds.) (1986). A transição incompleta: Brasil desde 1945 [in Portuguese]. Rio de Janeiro: Paz e Terra.

Backlund, E., Sorlie, P. D., \& Johnson, . N. J. (1996). The shape of the relationship between income and mortality in the United States: Evidence from the national longitudinal mortality study. Annals of Epidemiology, 6(1), 12-20.

Barnett, J. K., Papini, D. R., \& Gbur, E. (1991). Familial correlates of sexually active pregnant and non-pregnant adolescents. Adolescence, 26(102), 457-472.

Chiang, T. (1999). Economic transition and changing relation between income inequality and mortality in Taiwan: Regression analysis. British Medical Journal, 319(7218), 1162-1165.

Diez-Roux, A. V. (1998). Bringing context back into epidemiology: Variables and fallacies in multilevel analysis. American Journal of Public Health, 88(2), 216-222.

Diez-Roux, A. V., Link, B. G., \& Northridge, M. E. (2000). A multilevel analysis of inequality and cardiovascular disease risk factors. Social Science \& Medicine, 50(5), 673-687.

Duncan, G. J. (1996). Income dynamics and health. International Journal of Health Services, 26(3), 419-444.

Faber, N. B. (1991). The process of pregnancy resolution among adolescent mothers. Adolescence, 26(103), 697-716.

Farquhar, J. W., Fortmann, S. P., Flora, J. A., Taylor, C. B, Haskell, W. L., \& Williams, P. T., et al. (1990). Effects of communitywide education on cardiovascular disease risk 
factors. The Stanford Five-City Project. Journal of the American Medical Association, 264(3), 359-365.

Fiscella, K., \& Franks, P. (1997). Poverty or income inequality as predictor of mortality: Longitudinal cohort study. British Medical Journal, 314(7096), 1724-1727.

Gama, S. G. N., Szwarcwald, C. L., Leal, M. C., \& Theme Filha, M. M. (2001). Gravidez na adolescência como fator de risco para o baixo peso ao nascer no Município do Rio de Janeiro, 1996 a 1998 [in Portuguese]. Revista de Saúde Pública, 35(1), 74-80, in press.

Gravelle, H. (1998). How much of the relation between population mortality and unequal distribution of income is a statistical artefact. British Medical Journal, 316(7128), 382-385.

Humphreys, K., \& Carr-Hill, R. (1991). Area variations in health outcomes: Artifact or ecology. International Journal of Epidemiology, 20(1), 251-258.

Jargowsky, P. A. (1996). Take the money and run: Economic segregation in US metropolitan areas. American Sociological Review, 61(6), 984-998.

Kaplan, G. A., Pamuck, E. R., Lynch, J. W., Cohen, R. D., \& Balfour, J. L. (1996). Inequality in income and mortality in the United States: Analysis of mortality and potential pathways. British Medical Journal, 312(7037), 999-1003.

Kawachi, I., \& Kennedy, B. P. (1997). Health and social cohesion: Why care about income inequality. British Medical Journal, 314(7086), 1037-1040.

Kawachi, I., Kennedy, B. P., Lochner, K., \& Prothrow-Smith, D. (1997). Social capital, income inequality, and mortality. American Journal of Public Health, 87(9), 1491-1498.

Kennedy, B. P., Kawachi, I., Glass, R., \& Prothrow-Smith, D. (1998). Income distribution, socioeconomic status, and self rated health in the United States: Multilevel analysis. British Medical Journal, 317(7163), 917-921.

Kennedy, B. P., Kawachi, I., \& Prothrow-Smith, D. (1996). Income distribution and mortality: Cross sectional ecological study of the robin hood index in the United States. British Medical Journal, 312(7037), 1004-1007.

Lynch, J. W., Kaplan, G. A., Pamuk, E. R., Cohen, R. D., Heck, K. E., Balfour, J. L., \& Yen, I. H. (1998). Income inequality and mortality in metropolitan areas of the United States. American Journal of Public Health, 88(7), 1074-1080.

Lynch, J. W., Smith, G. D., Kaplan, G. A., \& House, J. S. (2000). Income inequality and mortality: Importance to health of individual income, psychosocial environment, or material conditions. British Medical Journal, 320(7243), 1200-1204.

Macintyre, S., Maciver, S., \& Sooman, A. (1993). Area, class and health: Should we be focusing on places or people?. Journal of Social Policy, 22, 213-234.

Marmot, M. G., Kogeniva, M., \& Elston, M. A. (1987). Socialeconomic status and health. Annual Review of Public Health, $8,111-135$.

Massey, D. S. (1996). The age of extremes: Concentrated affluence and poverty in the twenty-first century. Demography, 33(4), 395-412.

Monteiro, S. (1999). AIDS, sexuality and gender: The logic of self-protection in a deprived community of Rio de Janeiro [in Portuguese]. Doctoral Dissertation presented to the National School of Public Health, Oswaldo Cruz Foundation (FIOCRUZ).
Monteiro, C. A., \& Benicio, M. H. A. (1989). Determinants of infant mortality trends in developing countries: Some evidence from são paulo city. Transactions of the Royal Society of Tropical Medicine and Hygiene, 83(1), 5-9.

Puska, P., Tuomilehto, J., Nissinen, A., Salonen, J. T., Vartiainen, E., \& Pietinen, P., et al. (1989). The North Karelia Project: 15 years of community-based prevention of coronary heart disease. Annals of Medicine, 21(3), 169-173.

Reijneveld, S. A. (1998). The impact of individual and area characteristics on urban socioeconomic differences in health and smoking. International Journal of Epidemiology, 27(1), 33-40.

Rip, M. R., Keen, C. S., \& Woods, D. L. (1987). Intraurban variations of neonatal and post-neonatal mortality in a developing city. Social Science \& Medicine, 25(8), 889-894.

Sampson, R. J., Raudenbush, S. W., \& Earls, F. (1998). Neighborhoods and violent crime: A multilevel study of collective efficacy. Science, 277(5328), 918-924.

Sastry, N. (1996). Community characteristics, individual and household attributes, and child survival in Brazil. Demography, 33(2), 211-229.

Sciarra, D. T., \& Ponterotto, J. G. (1998). Adolescent motherhood among low-income urban hispanics: Familial considerations of mother-daughter dyads. Qualitative Health Research, 8(6), 751-763.

Sen, A. (1999). Health in development. Bulletin of the World Health Organization, 77(8), 619-623.

Shouls, S., Congdon, P., \& Curtis, S. (1996). Modeling inequality in reported long term illness in the UK: Combining individual and area characteristics. Journal of Epidemiology and Community Health, 50(3), 366-376.

Sloggett, A., \& Joshi, H. (1994). Higher mortality in deprived areas: Community or personal disadvantage? British Medical Journal, 309(6967), 1470-1474.

Smith, G. D. (1996). Income inequality and mortality: Why are they related. British Medical Journal, 312(7037), 987-988.

Sorlie, P. D., Backlund, E., \& Keller, J. B. (1995). US mortality by economic, demographic and social characteristics: The national longitudinal mortality study. American Journal of Public Health, 85(7), 949-956.

Stern, C. (1997). Teenage pregnancy as a public problem: A critical view [in spanish]. Salud Pública de México, 39(2), 137-143.

Szwarcwald, C. L., Bastos, F. I., Barcellos, C., Pina, M. F., \& Esteves, M. A. P. (2000). Health conditions and residential concentration of poverty: A study in Rio de Janeiro, Brazil. Journal of Epidemiology and Community Health, 54(7), 530-536.

Szwarcwald, C. L., Bastos, F. I., Viacava, F., \& Andrade, C. L. $\mathrm{T}$ (1999). Income inequality and homicide rates in Rio de Janeiro, Brazil. American Journal of Public Health, 89(6), 845-850.

Towsend, P., \& Davidson, N. (Eds.) (1990). Inequalities in health. The black report and the health divide. London: Penguin.

Upton, G.J.G., \& Fingleton, B. (1985). Spatial data analysis by example, point pattern and quantitative data, Vol. 1. New York: Wiley.

Victora, C. (2000). Potential interventions to improve the health of mothers and children in Brazil. Manuscript submitted to publication. 
Wilkinson, R. G. (1996). Unhealthy societies: The afflictions of inequality. London: Routledge.

Wilkinson, R. G. (1997). Health inequalities: Relative or absolute material standards? British Medical Journal, 314(x), 591-595.

Wolfson, M., Kaplan, G., Lynch, J., Ross, N., \& Backlund, E. (1999). Relation between income inequality and mortality: Empirical demonstration. British Medical Journal, 319(7215), 935-953.

Wong, G. Y., \& Mason, W. M. (1991). Contextually specific effects and other generalizations of the hierarchical linear model for comparative analysis. Journal of the American Statistical Association, 86(414), 487-503.

World Bank (1995). World Development Report 1995. Workers in an integrating world. New York: Oxford University Press.

Yen, H., \& Syme, S. L. (1999). The social environment and health: A discussion of the epidemiologic literature. Annual Review of Public Health, 20, 287-308.

Zar, J. H. (1996). Biostatistical analysis. New Jersey: Prentice Hall. 